\title{
Classification of Russian cities by levels of road traffic safety: specifics of required management decisions
}

\author{
Artur Petrov, ${ }^{1, *}$ and Daria Petrova ${ }^{2}$ \\ ${ }^{1}$ Tyumen Industrial University, Melnikaite street, 72-221, Tyumen, Russian Federation \\ ${ }^{2}$ Federal University named after the first President of Russia B.N. Yeltsin, Ekaterinburg, Chapaev \\ street, 16a-511, Ekaterinburg, Russian Federation
}

\begin{abstract}
The article considers the results of research of accident rate heterogeneity in cities-administrative centers of subjects of Russian Federation $(2015,2016)$. Using methods of ranging, regression analysis and spatial differentiation these cities were classified into 5 classes on the basis of relative disadvantage in road traffic safety sphere. For each group of cities differentiated recommendations on financing regional road traffic safety programs were suggested.
\end{abstract}

\section{Introduction}

During the last three years $(2015,2016,2017)$ the quality of road transport safety in Russia has grown up [1]. Many factors have contributed to this: scrupulous government attention to this issue [2], increased transport discipline [3], and, perhaps, declined transport mobility of Russians [4]. Meanwhile processes road traffic safety improvement are proceeding extremely heterogeneously in such a large and different from region to region country. Severity of road transport accidents (RTA) in Ingushetia in 2015-2017 was 17.6 dead on 100 injured, while in Chukotka Autonomous Okrug this indicator was equal to zero despite the fact that average value in whole Russian Federation is 8.1 dead on 100 injured [1]. This observation leads to the conclusion that it is necessary to manage the processes of road traffic safety organization differently, taking into the account the individual region, and using multiple technological methods. This approach will have an impact on the demanded financing of road traffic safety improvement.

\section{Formulation of the problem}

In the cities, especially in the administrative centers of the subjects of Russian Federation, people's living conditions and possibilities of road traffic safety provision are unified in a greater degree than in regions of country. It seems that in the cities indicators of accident

Corresponding author: ArtIgPetrov@yandex.ru 
usage of differentiated approaches to the solution of financing regional road traffic safety programs problem. Cities with a high accident rate level require additional financing and special control over its targeted use.

There are 3 sources of financing the road traffic safety programs - federal, regional and local budgets. Funds allocated from federal budget for provision the road traffic safety in the regions of country are not large (35.666 bln. rub. during 2013..2020 [2], taking into account, among the other funds, the consolidated budgets of Russian Federation subjects). Regions and municipality of country have a right to independently allocate the funds for the solution of the actual problems of road traffic safety improvement. For example, in Tyumen region financial provision in $2015 \ldots 2021$ can be up to 2.114 bln. rub. for a period of 7 years or, in other words, nearly $0.3 \%$ of average annual region budget [5]. In Russian cities, in addition to the regional road traffic safety improvements programs, there are also municipal ones. Amount of financing of these programs is not regulated by official documents. As a result, a serious heterogeneity of transport systems functioning conditions and, as a consequence, heterogeneity of accident rate were formed in Russian cities. In this connection there is a need in studying this phenomenon and classifying Russian citiesadministrative centers on the basis of relative disadvantage in the road traffic safety sphere.

Problems solved in this article:

- identification of Human Risk (HR) [6, 7, 8] value and of Road Transport Accidents (RTA) Severity [3] value in Russian cities-regional centers (2015/2016);

- ranging of Russian cities-regional centers on the basis of values of HR and of RTA Severity;

- building of regression models of relations between Russian cities ranks that were calculated on the basis of RTA Severity and HR value;

- spatial-qualitative analysis of cities on the basis of relative disadvantage in the road traffic safety sphere.

\section{Materials and Methods}

\subsection{Initial data}

The website of State inspection of road traffic of the Ministry of Internal Affairs of Russia [1] was used as the source of road accident rate data. Analysis of this data identified values of two indicators - HR [6, 7, 8] and RTA Severity [3] (table 1).

Table 1. Road accident rate indicators in several Russian regional centers (2016)

\begin{tabular}{|c|c|c|c|c|c|}
\hline \multirow[b]{2}{*}{$\begin{array}{l}\text { Russian regional } \\
\text { center }\end{array}$} & \multicolumn{5}{|c|}{ Numerical values of road accident rate indicators [1] } \\
\hline & $\begin{array}{l}\text { Population, } \\
\text { people } \\
\text { (at 1.01.17) }\end{array}$ & $\begin{array}{l}\text { Amount of } \\
\text { died in } \\
\text { road } \\
\text { accidents } \\
(2016)\end{array}$ & $\begin{array}{l}\text { Amount of } \\
\text { injured in } \\
\text { road } \\
\text { accidents } \\
(2016)\end{array}$ & $\begin{array}{l}\text { HR, dead } \\
\text { in road } \\
\text { accidents } / 1 \\
00 \text { thous. } \\
\text { citizens }\end{array}$ & $\begin{array}{c}\text { RTA } \\
\text { Severity, } \\
\text { died in road } \\
\text { accidents } \\
/ 100 \text { injured }\end{array}$ \\
\hline Tyumen & 720575 & 50 & 1942 & 6.94 & 2.51 \\
\hline Yekaterinburg & 1444439 & 85 & 1029 & 5.88 & 7.63 \\
\hline Grozny & 287410 & 29 & 240 & 10.09 & 10.78 \\
\hline \multicolumn{6}{|c|}{ } \\
\hline Moscow & 12325387 & 561 & 10326 & 4.55 & 5.15 \\
\hline
\end{tabular}


For the purpose of studying the road accident rate heterogeneity of Russian cities we used such tools as ranging Russian cities by two road accident rate indicators (1 stage) and aligning these indicators in accordance with RTA Severity and HR for each city (2 stage) with the aim of building the regression model ( 3 stage). On the basis of this model grouping and subsequent classifying of cities was held (4 stage). Usage of ranking method gives us a visual representation of spatial distribution of Russian cities relatively to each other in the coordinates "RTA Severity rank - HR rank" that allows objectively understand the shift of road traffic safety level in specific city relatively to the average Russian level.

\section{Results}

\subsection{Regression models of relations of ranks of Russian cities by RTA Severity and HR}

Fig. 1 shows graphical representation of models $(2015,2016)$ of statistical relations of Russian cities ranks by RTA Severity and HR. It is important to note that low ranks identify maximal values of road accident rate characteristics, i.e. point to cities with unfavorable situation in the road traffic safety sphere.

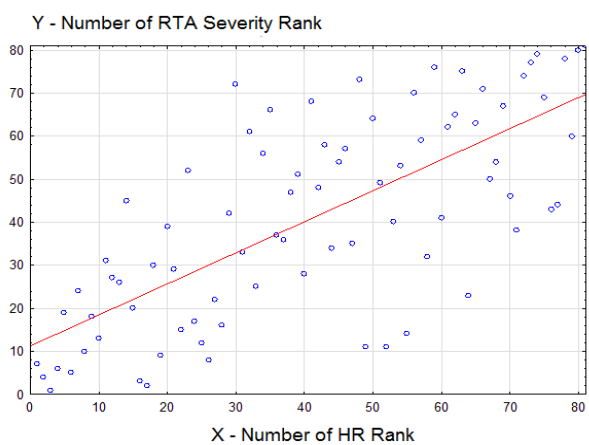

a). 2015 Year

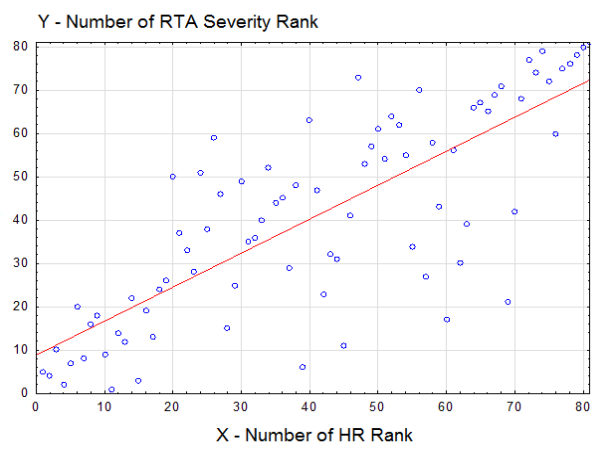

b). 2016 Year

Fig. 1. Graphical representation of models of statistical relations of ranks of Russian citiesadministrative centers by RTA Severity and HR

Models are almost identical. The insignificant difference between them is determined by the positive dynamics of road accident rate in 2016 relatively to 2015. Table 2 shows models, presented in fig. 1 , and their main statistical characteristics.

Table 2. Concretization of models and their statistical characteristics

\begin{tabular}{|c|c|c|c|c|}
\hline \multirow{2}{*}{ Regression model } & \multicolumn{3}{|c|}{ Values of statistical characteristics } \\
\cline { 2 - 5 } & $\mathrm{R}$ & $\mathrm{R}^{2}$ & $\mathrm{~F}$ & $\begin{array}{c}\text { St. error } \\
\text { of } \\
\text { estimate }\end{array}$ \\
\hline \multicolumn{5}{|c|}{ 2015 Year } \\
\hline RTA Severity Rank $=11.28+0.722$ HR Rank & 0.718 & 0.516 & 83.94 & 16.57 \\
\hline \multicolumn{6}{|c|}{ 2016 Year } \\
\hline RTA Severity Rank $=8.84+0.784$ HR Rank & 0.784 & 0.615 & 126.40 & 14.68 \\
\hline
\end{tabular}




\section{disadvantage in the road transport safety sphere}

Model, presented on fig. 1b (2016), was taken as a basis for grouping according to relative disadvantage in the road traffic safety sphere (fig. 2). With the usage of this grouping the classification of Russian cities was held.

\section{Y - Number of RTA Severity Rank}

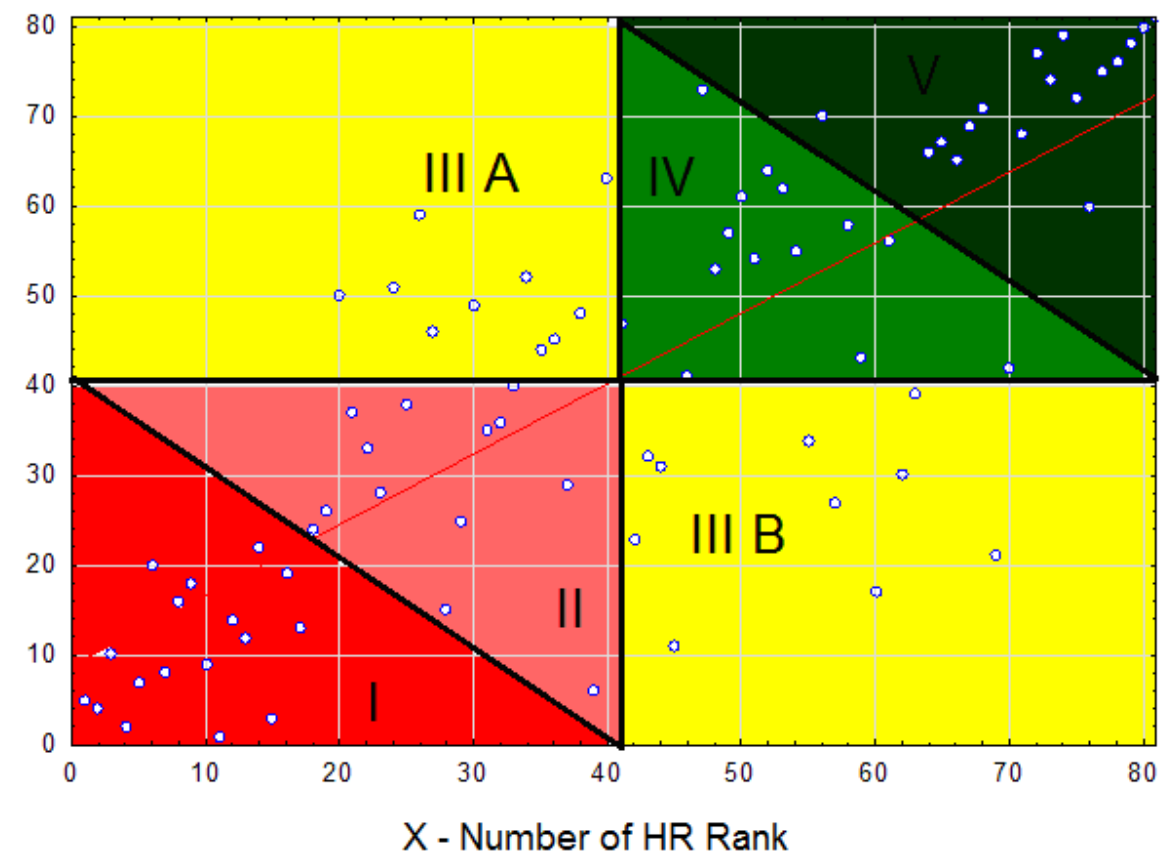

Fig. 2. Nomogram of classification of Russian cities by levels of road transport safety (2016)

I - class of cities with the most unfavorable road traffic safety sphere;

II ... IV - intermediate level or road traffic safety sphere;

$\mathrm{V}$ - class of cities with the most favorable road traffic safety sphere

Class I contains the most unfavorable cities in road traffic safety sphere which have a low rank by RTA Severity and HR. Vice versa, class V contains cities with the most favorable road traffic safety sphere, i.e. these cities have a high rank by road accident characteristics. Classes II-IV are intermediate. Class II is approximate to I class, and class IV is approximate to V class. Class III is divided into two parts - III A and III B. Cities of subclass III A have offset of problematics in the road traffic safety sphere in the direction of HR and cities of subclass III B have offset in the direction of RTA Severity. Other classes have relative accordance between HR and RTA Severity (in the paradigm "or everywhere it's bad, or everywhere it's good").

\section{Discussion}

Table 3 gives examples of several Russian cities that included in the road safety classes. 


\begin{tabular}{|c|c|c|c|}
\hline \multirow{2}{*}{$\begin{array}{l}\text { Classes of Russian } \\
\text { cities from the } \\
\text { perspective of road } \\
\text { traffic safety }\end{array}$} & \multicolumn{3}{|c|}{ Characteristics } \\
\hline & $\begin{array}{l}\text { Level of road } \\
\text { traffic safety }\end{array}$ & $\begin{array}{l}\text { Examples } \\
\text { of cities }\end{array}$ & $\begin{array}{l}\text { Generalized } \\
\text { characteristic }\end{array}$ \\
\hline I & Unacceptably low & $\begin{array}{c}\text { Grozny; } \\
\text { Nalchik; } \\
\text { Makhachkala; } \\
\text { Vladikavkaz }\end{array}$ & $\begin{array}{c}\text { Cities } \\
\text { of North Kavkaz }\end{array}$ \\
\hline II & Low & $\begin{array}{c}\text { Rostov-on-Don; } \\
\text { Stavropol; } \\
\text { Maikop; } \\
\text { Cherkessk } \\
\end{array}$ & $\begin{array}{c}\text { Cities } \\
\text { of Russian South }\end{array}$ \\
\hline III A & Medium 1 & $\begin{array}{l}\text { Tyumen; } \\
\text { Irkutsk; } \\
\text { Perm; } \\
\text { Orenburg }\end{array}$ & $\begin{array}{c}\text { Cities of Central } \\
\text { Russia with the } \\
\text { population } 500 \ldots 1000 \\
\text { thousands people }\end{array}$ \\
\hline III B & Medium 2 & $\begin{array}{c}\text { Moscow; } \\
\text { St. Petersburg; } \\
\text { Novosibirsk }\end{array}$ & $\begin{array}{c}\text { Biggest } \\
\text { Russian cities }\end{array}$ \\
\hline IV & High & $\begin{array}{c}\text { Chabarovsk } \\
\text { Krasnoyarsk } \\
\text { Omsk } \\
\text { Chelyabinsk }\end{array}$ & $\begin{array}{l}\text { Large cities of East } \\
\text { and Central Russia }\end{array}$ \\
\hline V & Very high & $\begin{array}{l}\text { Kostroma; } \\
\text { Vologda; } \\
\text { Murmansk; } \\
\text { Anadyr } \\
\end{array}$ & $\begin{array}{l}\text { Northern cities with } \\
\text { small population } \\
\text { (less than } 300 \\
\text { thousands people) }\end{array}$ \\
\hline
\end{tabular}

Analysis of classes content allows to make a conclusion that cities were divided into classes not only by level of road traffic safety but also geographically that is determined by socio-demographic composition of the population. For example, the Chechen Republic has the lowest average population age in the country -25.5 years [9]. That fact can make an impact on probabilistic deviance of behavioral reactions $[10,11]$.

Taking into account that at this moment in the Russian Federation there is no strict normative system for required investments in the road traffic safety provision sphere, it is necessary to recommend approximate expenses of regional budgets on a road traffic safety provision in Russian cities-administrative centers (table 4).

Table 4. Suggestions on investments in road traffic safety programs in different Russian cities

\begin{tabular}{|c|l|}
\hline $\begin{array}{c}\text { City's road traffic } \\
\text { safety class }\end{array}$ & \multicolumn{1}{c|}{ Suggestions on road traffic safety improvement } \\
\hline I (most unfavorable) & $\begin{array}{l}\text { It is necessary to invest in regional road traffic safety programs nearly } 1.0 \% \text { of } \\
\text { regional budget; }\end{array}$ \\
\hline II & $\begin{array}{l}\text { It is necessary to invest in regional road traffic safety programs nearly } 0.8 \% \text { of } \\
\text { regional budget; }\end{array}$ \\
\hline III & $\begin{array}{l}\text { It is necessary to invest in regional road traffic safety programs nearly } 0.6 \% \text { of } \\
\text { regional budget; }\end{array}$ \\
\hline IV & $\begin{array}{l}\text { It is necessary to invest in regional road traffic safety programs nearly } 0.4 \% \text { of } \\
\text { regional budget; }\end{array}$ \\
\hline V (most favorable) & $\begin{array}{l}\text { It is necessary to invest in regional road traffic safety programs nearly } 0.2 \% \text { of } \\
\text { regional budget; }\end{array}$ \\
\hline $\begin{array}{l}\text { Note. It is suggested to start usage of the differentiated system of administrative punishments for the } \\
\text { violators of the traffic code. In cities of classes I and II punishments should be plenty severe, while in } \\
\text { cities of classes IV and V-relatively liberal. }\end{array}$ \\
\hline
\end{tabular}


sphere of unfavorable cities (I and II classes). How proposed investments can change situation in the road traffic safety sphere? For example, today in Tyumen (III A class) only $0.31 \%$ of regional budget [5] are invested in events aimed at improvement of road traffic safety, while recommended value is $0.6 \%$. Double increasing of investments almost certainly will have a positive impact on a road traffic safety and Tyumen will be able to move from III A class to IV class.

\section{Conclusion}

Main conclusions are presented below.

1. Road accident rate in Russian administrative centers is extremely heterogeneous mostly because of various possibilities of financing road traffic safety provision programs in different regions.

2. With the usage of ranking of Russian cities-administrative centers by two road accident indicators - Human Risk (HR) and Road Transport Accidents (RTA) Severity the regression model RTA Severity Rank $=f(H R$ Rank) was built.

3. The nomogram of classification of Russian cities by levels of road transport safety was created on the basis of regression model RTA Severity Rank $=f(H R$ Rank).

4. Russian cities were grouped into 5 classes. I class contains cities with the most unfavorable road traffic safety - mostly cities of North Kavkaz. V class - cities with the most favorable road traffic safety - mainly Northern cities with a small population. II class includes cities of South Russia. IV class contains large cities of East Russia. III class includes cities of Central Russia.

5. To improve the road traffic safety, it is suggested to differentiate methods of investing in road traffic safety programs. Regions with cities belonging to I class should invest in road traffic safety programs nearly $1 \%$ of regional budget, while regions with cities belonging to $\mathrm{V}$ class should invest only $0.2 \%$ of regional budget.

Finally, implementation of these suggestions will help to execute targets of Strategy of road safety in the Russian Federation for 2018-2024 [12] such as reducing by 2024 the value of indicator HR to the level of 4 dead in road accidents/100 thous. citizens.

\section{Reference}

1. State inspection of road traffic. Indicators of road traffic safety. Available from: http://stat.gibdd.ru/ [Accessed 30th January 2018]

2. Federal Target Program for traffic safety for the period $2012 \ldots 2020$. Available from: https://rg.ru/20 13/10/08/bezopas-site-dok.html [Accessed 30th January 2018]

3. A. I. Petrov, Features of formation of motor transportation accident rate in space and time. (Tyumen: TyumGNGU, 2015)

4. Experts have noticed the addiction of the Russians to the reduction of consumption standards Available from: https://www.rbc.ru/society/11/01/2017/58762d949a 7947125b4b525f [Accessed 20th February 2018]

5. The Resolution of January 26, 2015 № 1-p "On the approval of the state target program of the Tyumen region «Road Safety improving until 2021»". Available from: http://docs.cntd.ru/document/424030873 [Accessed 30th January 2018]

6. R. J. Smeed, Some statistical aspects of road safety research. Journal of the Royal Statistical Society. Series A (General). Vol. 112, №. 1.112 (1): 1-34 (1949).

7. J. Adams, Risk. (London: UCL Press, 1995) 


\section{0-73 (1987)}

9. Russian Demographic Data Sheet 2016. Available from: http://population russia.ru/data/RussianDemographicDataSheet2016_web.pdf $\left[\right.$ Accessed 30 ${ }^{\text {th }}$ March 2018]

10. A. I. Petrov, Road traffic accident rate as an indicator of the quality of life. Economic and social changes: facts, trends, forecast. 3(45): 154-172 (2016). Available from: http://esc.isertran.ru/article/1907 [Accessed 30th March 2018]

11. V. I. Kolesov, A. I. Petrov, Analysis of transport culture population. Transport: science, equipment, management. 6: 20-22 (2015)

12. The Resolution of the Government of the Russian Federation of January 8, 2018 № 1-p "Strategy of road safety in the Russian Federation for 2018 - 2024". Available from: http://static.government.ru/media/files/g6BXGgDI4fCEiD4xDdJUwlxudPATBC12.pdf [Accessed 30th March 2018] 